\title{
Admission of Elderly in Emergency Units: Causes and Problems
}

Deepika Sharma, Manveer Kaur, Rohini Chaudhary, Sukhpal Kaur*, Meenakshi Agnihotri and Ashish Bhalla

National Institute of Nursing Education, Post Graduate Institute of Medical Education and Research, Chandigarh, India

\begin{abstract}
Background: Elderly population is the most vulnerable population. With the increase in age, there is decline in the body function and eventually the person becomes more prone to health problems.

Objective: To assess the causes and problems of elderly people visiting emergency units of a tertiary care centre.

Methodology: Using purposive sampling technique, 300 subjects with 100 each from emergency medicine, surgery and trauma units were enrolled in the study. Primarily the informants were the patients and in case the patients were not able to communicate, the information was obtained from the caregivers. The socio-demographic profile of the subjects and the physical, social, financial and the organizational setup problems in emergency being faced by them were noted.

Results: Mean age of patients was 68.18 yrs. Maximum admissions in medicine unit were because of cardiovascular problems and in the surgery unit gastrointestinal system problems were predominantly more. However, in trauma unit, $60 \%$ subjects were admitted with musculoskeletal problems e.g. fracture of upper and lower limbs. Hypertension was the leading co-morbidity in the subjects of all the three units. After approaching the respective units, $93 \%$ subjects in medicine, $83 \%$ subjects in surgical unit and $86 \%$ subjects in trauma were checked within one hour of their arrival in emergency. A total of $63 \%$ in medicine emergency unit, $48 \%$ subjects in surgical unit and $99 \%$ in trauma unit were not able to maintain their hygiene. In medicine $60 \%$ subjects, in surgical unit 59\% subjects, however in trauma unit 53\% subjects were not able to bear their financial expenses. As per organizational setup problems, insufficient beds and unsatisfactory sitting arrangement for relatives were the main problems reported by majority of the respondents in all the three units.
\end{abstract}

Conclusion: There is need to develop strategies to make the emergency departments more senior friendly.

Keywords: Elderly; Emergency unit; Problems

\section{Introduction}

Ageing is a normal, yet very complex process. As the body ages, the function of each system of body becomes impaired eventually giving rise to various health problems. This makes them frequent users of emergency units. Aminzadeh et al., has reported that older adults use emergency services at a higher rate, their visits have a greater level of urgency and they have longer stays in the emergency department. Even the elderly experience higher rates of adverse health outcomes after their discharge from hospital [1].

Many studies have been conducted to assess the problems of elderly people. Adverse drug effects, infection and COPD have been reported by Larsen [2]. Abdominal pain as the main complaint in 3\% to $13 \%$ of emergency department visits in older patients, has been shown by Samaras et al. [3]. Most of the elderly patients presented in the emergency departments with non specific complaints followed by shortness of breathe and fever [4].

Apart from medical problems, because of the decline in body function, the elderly are more prone to injury. The femur was most frequent fracture site among trauma patients as reported by Kara et al. [5].

The dependency level both physical and financial, amongst these patients also increases once they become unwell, particularly in hospital. With this background the current study was conducted with the objectives to explore the causes among elderly patients and to identify the problems of elderly patients attending emergency units, Nehru Hospital, PGIMER, Chandigarh.

\section{Methdology}

The current study was descriptive in nature.

Sample: Using purposive sampling technique, total 300 elderly patients with 100 each from medicine, surgery and trauma emergency units were included in the study.

Inclusion criteria: All the patients above 60 years of age, who were admitted in emergency for the last more than $24 \mathrm{hrs}$ and were willing to participate in the study were included.

Tools: An interview schedule was used to collect the data. It consisted of identification data, socio-demographic profile, health and clinical condition profile, physical, social, financial problems. The problems they face in all the emergency units were also noted.

Ethical considerations: Ethical approval was sought from Ethical committee of National Institute of Nursing Education, PGIMER, Chandigarh. Written permission for conducting the study was obtained from the heads of each department and the incharge of emergency.

${ }^{*}$ Corresponding author: Dr. Sukhpal Kaur, National Institute of Nursing Education, Post Graduate Institute of Medical Education and Research, Chandigarh-160012, India, Tel: 919888536964; E-mail: sukhpal.trehan@yahoo.in

Received June 14, 2016; Accepted July 12, 2016; Published July 19, 2016

Citation: Sharma D, Kaur M, Chaudhary R, Kaur S, Agnihotri M, et al. (2016) Admission of Elderly in Emergency Units: Causes and Problems. Adv Practice Nurs 2:119. doi: 10.4172/2573-0347.1000119

Copyright: $\odot 2016$ Sharma D, et al. This is an open-access article distributed under the terms of the Creative Commons Attribution License, which permits unrestricted use, distribution, and reproduction in any medium, provided the original author and source are credited. 
Citation: Sharma D, Kaur M, Chaudhary R, Kaur S, Agnihotri M, et al. (2016) Admission of Elderly in Emergency Units: Causes and Problems. Adv Practice Nurs 2:119. doi: 10.4172/2573-0347.1000119

Page 2 of 3

Informed consent was obtained from each subject after explaining the objectives, activities and duration of their involvement. They were assured of maintaining their confidentiality.

Statistical analysis: Data was analyzed using SPSS 16.0 version. Descriptive statistics was employed to analyze the data.

\section{Results}

Table 1 depicts socio demographic data of the subjects. Maximum subjects $(62.3 \%)$ were in the age group of $60-69$ years, followed by $24.3 \%$ in the age group of $70-79$ years and only $1.7 \%$ was above 90 years of age. More than half (63.3\%) were male subjects and belonged to urban area (55\%), 38\% were living alone. Half of the subjects were completely dependent for financial support on their care givers.

Table 2 depicts clinical diagnosis of the subjects in all the emergency units on the basis of different body systems. In medicine unit more patients (27\%) were admitted with problems of cardiovascular system, in surgery unit problems of gastrointestinal system were predominately more, however in trauma unit more patients were with musculoskeletal problems.

Table 3 depicts the organizational problems of the subjects/ caregivers in emergency. It indicates that about half (41.3\%) of these subjects were not able to sleep properly. Problems regarding sitting arrangement for the attendants, insufficient beds for patients and overcrowding etc., were reported by majority of the subjects. Maximum were staying in the waiting hall followed by rain shelters (tents outside the institute) and shrine.

\begin{tabular}{|c|c|}
\hline Variables & $\mathbf{N}(\%)$ \\
\hline $\begin{array}{c}\text { Age ( years) (Mean } \pm \text { S. } D=68.18 \pm 7.98 \text { Range }=60-92) \\
60-69 \\
70-79 \\
80-89 \\
90-92\end{array}$ & $\begin{array}{c}187(62.3) \\
73(24.3) \\
35(11.7) \\
5(1.7)\end{array}$ \\
\hline $\begin{array}{c}\text { Gender } \\
\text { Male } \\
\text { Female }\end{array}$ & $190(63.3) \quad 110(36.7$ \\
\hline $\begin{array}{l}\text { Habitat } \\
\text { Rural } \\
\text { Urban }\end{array}$ & $\begin{array}{l}135(45.0) \\
165(55.0)\end{array}$ \\
\hline $\begin{array}{l}\text { Marital status } \\
\text { Married } \\
\text { Unmarried } \\
\text { Divorce } \\
\text { Widow/Widower }\end{array}$ & $\begin{array}{c}234(78.0) \\
7(2.3) 3(1.0) 56 \\
(18.7)\end{array}$ \\
\hline $\begin{array}{c}\text { Educational status } \\
\text { Illiterate } \\
\text { Primary } \\
\text { Middle } \\
\text { Matriculation } \\
\text { Senior secondary } \\
\text { Graduate or above }\end{array}$ & $\begin{array}{c}112(37.3) 57(19.0) \\
63(21.0) 44(14.7) 19 \\
(6.3) 5(1.7)\end{array}$ \\
\hline $\begin{array}{l}\text { Occupation } \\
\text { Working } \\
\text { Not working }\end{array}$ & $\begin{array}{l}117(39.0) \\
183(61.0)\end{array}$ \\
\hline $\begin{array}{l}\text { Type of Family } \\
\text { Nuclear } \\
\text { Joint }\end{array}$ & $\begin{array}{l}115(38.3) \\
185(61.7)\end{array}$ \\
\hline $\begin{array}{c}\text { Financial status } \\
\text { Completely dependent } \\
\text { Partially dependent } \\
\text { Independent }\end{array}$ & $\begin{array}{c}149(49.7) 62(20.7) \\
89(29.7)\end{array}$ \\
\hline
\end{tabular}

Table 1: Sociodemographic profile of the subjects.

\begin{tabular}{|l|c|c|c|c|}
\hline $\begin{array}{l}\text { Clinical diagnosis related to } \\
\text { various systems }\end{array}$ & $\begin{array}{c}\text { Medicine } \\
\text { unit } \\
\mathbf{n = 1 0 0}\end{array}$ & $\begin{array}{c}\text { Surgery } \\
\text { Unit } \\
\mathbf{n = 1 0 0}\end{array}$ & $\begin{array}{c}\text { Trauma } \\
\text { Unit } \\
\mathbf{n = 1 0 0}\end{array}$ & $\begin{array}{c}\text { Total N } \\
\text { (\%) }\end{array}$ \\
\hline $\begin{array}{l}\text { Neurological system (head injury, } \\
\text { CVA, meningioma, hydrocephalus) }\end{array}$ & 20 & 20 & 53 & $93(31)$ \\
\hline $\begin{array}{l}\text { Musculoskeletal system (fracture of } \\
\text { lower limb, upper limb, ribs, spinal } \\
\text { injury) }\end{array}$ & - & - & 60 & $60(20)$ \\
\hline $\begin{array}{l}\text { Gastrointestinal system } \\
\text { (cholelithiasis, intestinal obstruction, } \\
\text { Ca anus, acute liver disease, Ca } \\
\text { stomach) }\end{array}$ & 11 & 31 & - & $42(14)$ \\
\hline $\begin{array}{l}\text { Genitourinary system (Ca urinary, } \\
\text { Ca prostate, ca bladder, CKD, BPH, } \\
\text { Acute kidney injury) }\end{array}$ & 15 & 19 & & $34(11.3)$ \\
\hline $\begin{array}{l}\text { Cardiovascular system } \\
\text { (Hypertension, CAD, CCF, LVF, } \\
\text { acute limb ischemia) }\end{array}$ & 27 & 4 & - & $31(10.3)$ \\
\hline $\begin{array}{l}\text { Respiratory system (COPD, } \\
\text { pneumonia, Community acquired } \\
\text { pneumonia, PTB) }\end{array}$ & 23 & 1 & - & $28(9.3)$ \\
\hline $\begin{array}{l}\text { Endocrine system (DM, } \\
\text { hypothyroidism) }\end{array}$ & 5 & 8 & - & $13(4.3)$ \\
\hline $\begin{array}{l}\text { Reproductive system (Ca breast, } \\
\text { ovarian cancer) }\end{array}$ & - & 6 & - & $06(2.0)$ \\
\hline
\end{tabular}

Table 2: Diagnosis of the subjects in emergency units. $\mathrm{N}=300$.

\begin{tabular}{|l|c|c|c|c|}
\hline Problems & $\begin{array}{c}\text { Medicine } \\
\text { unit n=100 }\end{array}$ & $\begin{array}{c}\text { Surgery } \\
\text { unit n=100 }\end{array}$ & $\begin{array}{c}\text { Trauma } \\
\text { unit n=100 }\end{array}$ & $\begin{array}{c}\text { Total N } \\
\text { (\%) }\end{array}$ \\
\hline Sleep Problems & 39 & 52 & 33 & $124(41.3)$ \\
\hline $\begin{array}{l}\text { Related to sitting arrangement } \\
\text { for attendants }\end{array}$ & 81 & 77 & 82 & $240(80)$ \\
\hline Relatives were staying & & & & \\
\hline Emergency waiting hall & 60 & 51 & 82 & $133(44.3)$ \\
\hline Rain shelter (tents) & 26 & 19 & 2 & $47(15.6)$ \\
\hline Shrine & 10 & 25 & 8 & $43(14.3)$ \\
\hline On rent & 2 & 5 & 5 & $12(4)$ \\
\hline Own house & 2 & 0 & 3 & $5(1.6)$ \\
\hline During investigation & 28 & 42 & 18 & $88(29.3)$ \\
\hline Over Crowded & 33 & 25 & 35 & $186(62)$ \\
\hline Not oriented to the hospital & 5 & 10 & 16 & $31(10.3)$ \\
\hline Pulling stretcher & 5 & 2 & 2 & $9(3)$ \\
\hline Long distance between the & & & & $164(54.6)$ \\
\hline different investigation centers & 69 & 54 & 41 & $259(86.3)$ \\
\hline Lack of staff & 87 & 88 & 84 & $269(89.6)$ \\
\hline Lack of beds & 87 & 90 & 92 & $182(60.6)$ \\
\hline Over Crowded & 71 & 66 & 45 & $157(52.3)$ \\
\hline Lack of toilets & 58 & 58 & 41 & \\
\hline Lack of toilet sanitation & & & & \\
\hline
\end{tabular}

Table 3: Problems faced by the subjects and their caregivers in emergency units.

\section{Discussion}

This world is seeing a tremendous rise in elderly population. According to WHO, globally elderly population is growing faster than any age group. In 2010, about 600 million people were 60 years or older, by 2025 figure is expected to reach 1.2 billion people and in 2050 it is likely to be around 1.9 billion. In developing countries the proportion of elderly will increase from $7 \%$ to $12 \%$ by 2025 [6]. India is the second most popular country in the world. It has 76.6 million people at or over the age of 60 , which constitute above $7.7 \%$ of total population [7].

The elderly population is one of the most vulnerable and neglected section of society. So this section needs more care, attention to improve 
their quality of life. Over the period of time, the elderly people become more susceptible to disease and disability. They often have limited regenerative abilities and are more prone to disease, various symptoms, and sickness than younger adults. Often they suffer from many health problems requiring emergency management. From health perspective it is more important to recognize the emergency health problems and health needs of elderly and to take steps to promote emergency health facilities.

The present study was undertaken with the objective to determine the causes of emergency admission among elderly and to enumerate problem faced by the elderly and their caregivers in various emergency units i.e. medicine, surgery and trauma.

As per planned methodology the subject were selected through purposive sampling technique. 300 subjects were enrolled with 100 from each unit. Data was collected from the subjects and caregivers by using an interview schedule. More than half of subjects (62.3\%) were in the age group of $60-69 \mathrm{yrs}, 63.3 \%$ subjects were male, $78 \%$ were married and $18.7 \%$ were widow/widower. Around one third were still working. More number of males using emergency unit has been reported by Stori et al., in their study [8]. Generally it has been seen that the males live longer than females. It is obvious that health problems will also be more in males. And generally also it has been seen that the males are comparatively better looked after than the females.

It is the accepted fact that with advancing age, the functioning of all the body system gets impaired. There is loss of tissue, overall strength, cognitive and motor function. They become more prone to fractures and disabilities. In present study out of 100 patients in trauma unit, $63 \%$ had various types of injuries due to fall or road side accidents. Similar results have been reported by Kara et al in their study [5].

Likelihood of developing health problems and chronic health problems increases as the body ages. The First National Sample Survey (NSS) conducted during the second half of 1980s, focused on the elderly had indicated that $45 \%$ of the elderly suffered from some chronic illness like pain in the joints and cough. Other diseases noted in the NSS survey included blood pressure, heart disease, urinary problems and diabetes [9]. In present study it was revealed that in $45 \%$ subjects from medicine unit, $21 \%$ from surgery unit and $28 \%$ from trauma unit have hypertension as a co-morbidity.

In the current study, $17 \%$ subjects from surgical emergency unit had gastrointestinal system related symptom at the time of admission like nausea, vomiting, abdominal distention, pain abdomen etc. It could be explained by the fact that in most of the elderly cases, it is usually observed that they start behaving like children. They do not realize what they should be eating. So, they may not digest whatever they eat and land up with acute GI problems. Our findings of having more admission of the subjects with GI problems has been supported by a study conducted on elderly patients in emergency department Geneva, Switzerland, that abdominal complaint was the main complaint in 3\% to $13 \%$ of emergency department visits in older patient.

In the present study it was found that $61 \%$ subjects were not working. In Indian settings, in majority of the states, the age of superannuation is 60 years, though it is 58 yrs and even 65 yrs in certain other states. So, after retirement from the job, the elderly become dependent on their caregivers, more so, if there is no pension. In the current study,
$50 \%$ of the subjects were completely dependent and $20 \%$ were partially dependent on their caregivers, though $30 \%$ were independently managing their financial aspects.

PGIMER Chandigarh is a tertiary care hospital. There has been unprecedented rise in the number of patients every year from all over North India. More number of patients and attendant needs more space and proper sitting arrangements. The findings of the present study revealed that most of the subjects $(80 \%)$ had problem related to sitting arrangement for their relatives.

Another common problem which was faced by $60 \%$ the patients/ caregivers was regarding the location of labs etc. and being not oriented to the hospital. They verbalized that there should be more staff appointed who can guide them, so that their precious time can be saved. To overcome this problem, in fact, more signboards in regional languages showing the way to various locations inside the hospital should be displayed.

These are a need to develop strategies to make the emergency department more senior friendly. We need to develop model of care in emergency for the older people customized to the Indian population. The previous models for the elderly care have mixed results. One study has reported that early geriatric assessment provided by a nurse specialist had no effect on admission rates, length of stay, or functional decline [10]. However, in another study, a nurse dedicated specifically to discharge planning for older adults reduced the proportion of unscheduled emergency return visits and facilitated the transition from emergency back home and into the community [11].

So, proportional to the increase in elderly population in future, the emergency admission of this vulnerable segment is also likely to increase. Thus, we need to develop certain policies to provide quality care to the elderly patients as well as their caregivers. In a qualitative study [12] carried out on 527 registered nurses from 49 US hospitals, five central themes were emerged from the analysis. These represented a lack of older person hospital environment fit in the emergency department. These themes were respect for the older adults and their care givers, correct and best procedures and treatment, time and staff to do things right, transitions, and a safe and enabling environment. The nurses offered solutions to address lack of fit, including modifications to the social climate, policies and procedures, care systems and processes, and physical design. So, the problems identified and the solutions offered by nurses could be helpful in planning strategies for the care of elderly people in emergency.

\section{References}

1. Aminzadeh F, Dalziel WB (2002) Older adults in the emergency department: a systematic review of patterns of use, adverse outcomes, and effectiveness of interventions. Ann Emerg Med 39: 238-47.

2. Larsen D (2015) Top 10 Reasons Seniors End Up in the ER.

3. Samaras N, Chevalley T, Samaras D, Gold G (2010) Older Patients in the Emergency Department: A Review. Ann Emerg Med 56: 261-269.

4. Trzeciak S, Rivers EP (2003) Emergency department overcrowding in the United States: an emerging threat to patient safety and public health. Emerg Med J 20: 402-405.

5. Kara H, Bayir A, Ahmet AK, Akinci M, Tufekci N, et al. (2014) A retrospective study: Trauma in elderly patients evaluated in a hospital emergency department in Konya, Turkey. Clin Inter Aging 9: 17-21.

6. Davies A (1999) Aging and health in the 21th century: An overview. In aging and health: A global challenge for 21th century. Geneva 1998. 
Citation: Sharma D, Kaur M, Chaudhary R, Kaur S, Agnihotri M, et al. (2016) Admission of Elderly in Emergency Units: Causes and Problems. Adv Practice Nurs 2:119. doi: 10.4172/2573-0347.1000119

Page 4 of 3

7. Krishnaswamy B, Gnanasambandam U. Falls In Older People: National/ Regional Review.

8. Storti LB, Fabrício-Whebe CCS, Kusumota L, Rodrigues RAP, Marques S (2013) Frailty of elderly patients admitted to medical clinic of an Emergency unit at a general hospital Text Context Nursing, Florianópolis 22: 452-459.

9. Rajan SI (2006) Population Ageing and Health in India. Centre for Enquiry into health and allied themes.

10. Basic D, Conforti DA (2005) A prospective, randomised, controlled trial of an aged care nurse intervention within the Emergency Department. Aust Health Rev 29: 51-59.

11. Guttman A, Afilalo M, Guttman R, Colacone A, Robitaille C, et al. (2004) An emergency department-based discharge coordinator for elder patients: Does it make a difference? Acad Emerg Med11: 1318-1327.

12. Boltz M, Parke B, Shuluk J, Capezuti E, Galvin JE (2013) Care of the Older Adult in the Emergency Department: Nurses Views of the Pressing Issues. Gerontologist 53: 441-453. 